\title{
Red blood cell microrheological changes and drug transport efficiency
}

\author{
Alexei Muravyov* and Irina Tikhomirova \\ Department of Medicine and Biology, State Pedagogical University, Yaroslavl, Russia
}

\begin{abstract}
The purpose of this study was to estimate drug effect on red blood cell (RBC) microrheological properties making for blood transport efficiency. It is well known that blood flow in microcirculation, tissue perfusion and oxygenation depend on red blood cell (RBC) microrheological properties, namely deformability (RBCD) and aggregability (RBCA). In turn the changed red cell mechanical properties can influence the tissue oxygenation as well as the drug delivery to tissues. The exposure of RBCs to agonist of $\beta$-adrenergic receptors (isoproterenol) caused RBCA decrease and an increase of their deformability. The prostaglandin $\mathrm{E}_{1}$, prostacyclin and insulin showed the similar positive microrheological effect. Neutral microrheological effect was fixed after cell incubation with 5-fluorouracil, rolipram and phorbol 12-myristate 13-acetate; no significant alterations of microrheological properties were found. The agonists of $\alpha$-adrenergic receptors and prostaglandin $\mathrm{F}_{2 \alpha}$ showed the negative microrheological effect: RBCD was markedly worsened and RBCA was enhanced by 49-60\%. It was found that three PDE inhibitors: vinpocetine, rolipram and cilostasol - significantly decreased RBCA and increased RBCD. Therefore PDEs might be considered as red blood cell molecular targets for some drugs. Stimulated by A23187 $\mathrm{Ca}^{2+}$ influx was accompanied by an increase of RBCA and a decrease of RBCD. The blocking of $\mathrm{Ca}^{2+}$ entry into the RBCs by verapamil led to a significant positive $\mathrm{RBC}$ changes. Therefore the red cell membrane $\mathrm{Ca}^{2+}$ channels can be considered as molecular targets responsible for red cell microrheology modifications too. Taken together the obtained data showed that the drugs infused in blood flow can interact with blood cells, including the most numerous cell population - red blood cells. This interaction can lead to an alteration of RBC microrheological properties and blood transport possibilities at least according to three abovementioned scenarios.
\end{abstract}

Keywords: Red blood cell aggregation and deformability, drugs, microrheological effect, cellular signaling pathways

\section{Introduction}

Blood flow in microcirculation, tissue perfusion and oxygenation depend on red blood cell (RBC) microrheological properties; namely deformability and aggregation [8, 19]. Drugs and signaling molecules can affect microrheological properties of blood cells including red cell aggregability and deformability $[4,6]$. It is known that at the capillary level the blood flow efficiency depends on red cell microrheological properties [21], and their alterations can influence not only on the tissue oxygenation [11] but also affect the drug delivery to tissue. Three variations of drug effect on red cell microrheology can be distinguished by the probable red cell microrheological changes after drug treatment: 1) drug has no effect on the red cell aggregability and deformability and blood transport capacity doesn't change it is neutral effect; 2) drug decreases red cell deformability and increases red cell aggregation - it is negative effect; and 3) drug increases red cell deformability and decreases red cell aggregation (RBCA) it is positive effect. One of the well-known rheologically "positive" drugs is pentoxifylline [8]. The

\footnotetext{
*Corresponding author: Alexei Muravyov, Department of Medicine and Biology, State Pedagogical University, Yaroslavl, Russia. Tel.: +007 8452 728633; Fax: +007 8452 305596; E-mail: alexei.47@ mail.ru.
} 
main mechanism of pentoxifylline blood rheological efficiency is connected with its phosphodiesterase (PDE) inhibitory activity [7]. The other drugs, having phosphodiesterase as intracellular targets, can be microrheologically active both in vitro and in vivo [16]. It is important to note that the red blood cells were historically considered inert to the regulatory signals from other cells. However they are surprisingly well equipped with the machinery required for intercellular communication $[13,15,20]$. It has been proven experimentally that the RBC membrane contains $\alpha$-and $\beta$-adrenoreceptors [20,23], insulin receptors [3], and cholinergic muscarinic receptors [26]. Note that the marked changes of red blood cell microrheological properties such as red cell deformability and aggregation are mediated by an activation of the molecular control mechanisms [12, 13, 15, 20].

The present study was designed to explore the effects of some drugs and chemicals as the signaling molecules on red blood cell microrheological properties.

\section{Materials and methods}

\subsection{Preparation of blood samples}

Venous blood samples $(15 \mathrm{ml})$ were drawn via sterile venipuncture using heparin $(5 \mathrm{IU} / \mathrm{ml})$ as anticoagulant. The study was approved by the local ethic committee at the Yaroslavl State Pedagogical University, and an informed consent of all the subjects were obtained according to the recommendations of the Declaration of Helsinki (The International Response to Helsinki VI, The WMA's Declaration of Helsinki on Ethical Principles for Medical Research Involving Human Subjects, as adopted by the 52nd WMA General Assembly, Edinburgh, October, 2000).

Red blood cells (RBCs) were separated by centrifugation at $1,400 \mathrm{~g}$ for $20 \mathrm{~min}$ and washed 3 times with $10 \mathrm{mM}$ phosphate buffered saline (PBS) $(\mathrm{pH}=7.4)$. The washed RBCs were then resuspended in PBS at a hematocrit (Hct) of approximately $40 \%$ for incubation with drugs or chemicals (experimental panel) and without any drugs (control panel). After an incubation period the supernatant was removed by centrifugation and cells were resuspended in autologous plasma at $\mathrm{Hct}=40 \%$ for measurement of RBC aggregation and deformability.

\subsection{Protocols for in vitro aggregation studies}

It was organized fourth research sessions. In the first one $\mathrm{RBC}$ suspension was divided into four aliquots and exposed to: 1) Isoproterenol (1.0 $\mu \mathrm{M}) ; 2)$ Insulin $0.1 \mu \mathrm{M})$; 3) Prostaglandins ( $\left.\left.\mathrm{PGE}_{1}, 0.01 \mu \mathrm{M}\right) ; 4\right)$ Prostacyclin $\left(\mathrm{PGI}_{2}, 0.01 \mu \mathrm{M}\right)$.

In the second research session $\mathrm{RBC}$ suspension aliquots exposed to: 1) 5-fluorouracil (5-FU, $5 \mu \mathrm{M}) ; 2)$ Inhibitor of the protein kinase $\mathrm{C}$ (PKC) activity, phorbol 12-myristate 13-acetate (PMA, $3 \mu \mathrm{M} ; n=24$ ); 3) $\mathrm{PDE}_{4}$ inhibitor rolipram $(10 \mu \mathrm{M} ; n=24)$.

In the third research session $\mathrm{RBC}$ suspension aliquots exposed to: 1) prostaglandin $\mathrm{F}_{2 a}\left(\mathrm{PGF}_{2 a}\right.$, $0.01 \mu \mathrm{M})$; 2) phenylephrine - alpha-1-adrenoceptor agonist (1.0 $\mu \mathrm{M})$; 3) clonidine alpha-2-adrenoceptor agonist $(1.0 \mu \mathrm{M})$.

In the fourth research session $\mathrm{RBC}$ suspension aliquots exposed to: 1) calcium ionophore A23187 $(3 \mu \mathrm{M}) ; 2)$ verapamil $-\mathrm{Ca}^{2+}$ channel blocker $(10 \mu \mathrm{M})$. In this research session the Ringer's solution was used as suspension medium, containing $\mathrm{Ca}^{2+}$. 
To study the role of phosphodiesterases (PDEs) in red cell microrheology alterations the cells were incubated with: $\mathrm{PDE}_{1}$ inhibitor vinpocetine $\left(10 \mu \mathrm{M} ; \mathrm{PDE}_{3}\right.$ inhibitor cilostazol $(10 \mu \mathrm{M})$ and PDE4 inhibitor rolipram $(10 \mu \mathrm{M})$. The cell shape was controlled with the light microscopy. The cell incubation was performed at $37^{\circ} \mathrm{C}$ for $15 \mathrm{~min}$. The red blood cells, incubated in the phosphate buffered saline (or in Ringer's solution) without any drugs, were used as a control. Stock solutions of drugs were prepared in DMSO or water. All analyses were completed within $4 \mathrm{~h}$ after the blood collection. Drugs and chemical compounds were mainly purchased from Sigma.

\subsection{Red blood cell aggregation measurement}

Red blood cell aggregation (RBCA) in native plasma was assessed by the Myrenne Aggregometer which provides an index of RBC aggregation facilitated by low shear. In brief, the suspension was subjected to a short period of high shear to disrupt pre-existing aggregates, following which the shear was abruptly reduced to $3 \mathrm{~s}^{-1}$ and light transmission through the suspension was integrated for 5 seconds; the resulting index, termed " $\mathrm{M}_{5}$ " by the manufacturer and "RBCA" herein, increased with enhanced RBC aggregation.

To estimate the deformability of RBCs the latter were placed into a flow microchamber. The cells were attached to the bottom part of the chamber with "one point" and then were deformed by shear flow under constant shear stress $(\tau)$. At a given volume flow rate $Q$ (determined by weighing the amount of saline which flows through the flow channel in a given time period) the shear stress at the surfaces $\tau$, is given by [2]:

$$
\tau=6 \eta Q / w h^{2},
$$

where $\eta$ is the viscosity of the perfusate, $w$ is the width and $\boldsymbol{h}$ is the height of the flow passageway. In our experiments, $\eta=1.07 \mathrm{mPa} \cdot \mathrm{s}, w=0.90 \mathrm{~cm}, h=0.01 \mathrm{~cm}$.

\subsection{Miscellaneous techniques}

The whole blood and red cell suspension hematocrite was determined via the microhematocrit method (i.e., $12,000 \times \mathrm{g}$ for 7 minutes).

\subsection{Statistics and data presentation}

The results are presented as mean SEM. The differences between the mean values were evaluated using an ANOVA test. The values of $p<0.05$ indicate statistical significance.

\section{Results}

\subsection{The relatively positive microrheological effect of the drugs}

Catecholamines as stress hormones ensure an effective adaptation to various factors of the environmental. It is important to note that human erythrocyte membranes contain both $\alpha_{1}$ - and $\beta_{2}$ - adrenergic receptors. In the presence of $1.0 \mu \mathrm{M}$ Isoproterenol the red blood cell aggregation was decreased to some extent versus control but not statistically (Table 1), while RBCD was significantly increased by $26 \%$ $(p<0.05)$ under these conditions. It is well known that insulin is a functional antagonist of the catecholamines, and erythrocytes possess insulin receptors. Therefore it may be assume that the red cell microrheology will be altered after the cell incubation with insulin. 
Table 1

The RBC microrheology alterations after cell incubation with some drugs (Positive hemorheological effect) $(\mathrm{M} \pm \mathrm{m} ; n=24)$

\begin{tabular}{lccccc}
\hline Parameter & Control & Isoproterenol $(1.0 \mu \mathrm{M}) ;$ & Insulin $(0.1 \mu \mathrm{M})$ & PGE $_{1}(0.01 \mu \mathrm{M})$ & PGI $_{2}(0.01 \mu \mathrm{M})$ \\
\hline RBCA & $7.20 \pm 0.26$ & $6.94 \pm 0.16$ & $3.98 \pm 0.18^{*}$ & $3.88 \pm 0.18^{*}$ & $4.28 \pm 0.36^{*}$ \\
RBCD & $0.198 \pm 0.006$ & $0.249 \pm 0.005^{*}$ & $0.228 \pm 0.005^{*}$ & $0.239 \pm 0.004$ & $0.242 \pm 0.005$ \\
\hline
\end{tabular}

${ }^{*} p<0.05$ versus control. Abbreviations: RBCA - red blood cell aggregation; RBCD - red blood cell deformability; PGE1 Prostaglandin $\mathrm{E}_{1} ; \mathrm{PGI}_{2}$ - Prostacyclin

Table 2

The RBCA and RBCD alterations after cell incubation with some drugs (Neutral hemorheological effect) $(\mathrm{M} \pm \mathrm{m} ; n=24)$

\begin{tabular}{lcccc}
\hline Parameter & Control & 5-FU $(5 \mu \mathrm{M})$ & Rolipram $(10 \mu \mathrm{M})$ & PMA $(3 \mu \mathrm{M})$ \\
\hline RBCA & $7.14 \pm 0.15$ & $7.24 \pm 0.18$ & $6.68 \pm 0.36$ & $7.29 \pm 0.26$ \\
RBCD & $0.208 \pm 0.006$ & $0.202 \pm 0.007$ & $0.220 \pm 0.007$ & $0.215 \pm 0.005$
\end{tabular}

Abbreviations: 5-FU - 5-fluorouracil; PMA - phorbol 12-myristate 13-acetate.

We have tested this hypothesis and found the RBCA was decreased by 44\% $(p<0.05)$ and RBCD was increased by $16 \%(p<0.05)$ versus control. The similar positive effect was observed after RBC incubation with Prostaglandin E1 and Prostacyclin (Table 1).

\subsection{The relatively neutral microrheological effect of the drugs}

5-fluorouracil is a drug for cancer chemotherapy and it employs for this purpose. It was found that this chemical has a neutral microrheological effect. Neither RBCA nor RBCD were changed significantly after the cell incubation with this drug (Table 2). $\mathrm{PDE}_{4}$ inhibitor rolipram also possess the relatively neutral effect on RBC microrheological behavior. Changes of red cell microrheology (up to 6\%) were not significant (Table 2). PMA is an activator of cellular protein kinase, mainly PKC. It was shown minor alteration (by 2-3\%) of red cell microrheological properties, both RBCA and RBCD after PMA treatment (Table 2).

\subsection{The relatively negative microrheological effect of the drugs}

The prostaglandin of $\mathrm{F}$ family $-\mathrm{PGF}_{2 \alpha}$ intensified the red cell aggregation. In presence of $\mathrm{PGF}_{2 \alpha}$ erythrocyte aggregation increased by $66 \%, p<0.05$ (Table 3 ). $\mathrm{PGF}_{2 \alpha}$ is known as a calcium cell entry stimulator [20]. Therefore the aggregation rise may be associated with an augmentation of $\mathrm{Ca}^{2+}$ influx.

In the presence of $1.0 \mu \mathrm{M} \alpha_{1}$ - and $\alpha_{2}$-receptor agonists (phenylephrine and clonidine) the red blood cell aggregation was markedly increased - from 49 to $60 \%$ (vs. control; $P<0.05$ ). The most significant aggregation effect had $\alpha_{2}$-agonist clonidine. After the cells incubation with this drug the RBCA was increased by $60 \%$ (Table 3 ). Therefore, it concerns mostly $\alpha$-adrenergic receptor stimulation by epinephrine or specific $\alpha$-agonists. On the contrary, these alpha-receptor agonists had the lowering RBCD effect (Table 3 ). On the whole, the obtained data make us believe that an activation of the red blood cell alpha-receptor is associated with a relative negative microrheological effect. 
Table 3

The RBCA and RBCD alterations after cell incubation with some drugs (Negative hemorheological effect) $(\mathrm{M} \pm \mathrm{m} ; n=24)$

\begin{tabular}{lcccc}
\hline Parameter & Control & $\operatorname{PGF}_{2 \alpha}(0.01 \mu \mathrm{M})$ & Phenylephrine $(1.0 \mu \mathrm{M})$ & Clonidine $(1.0 \mu \mathrm{M})$ \\
\hline RBCA & $7.34 \pm 0.26$ & $12.18 \pm 0.43^{*}$ & $10.96 \pm 0.32^{*}$ & $11.74 \pm 0.34^{*}$ \\
RBCD & $0.206 \pm 0.005$ & $0.189 \pm 0.005^{*}$ & $0.192 \pm 0.004^{*}$ & $0.196 \pm 0.004$
\end{tabular}

${ }^{*} p<0.05$ versus control. Abbreviations: $\mathrm{RBCA}$ - red blood cell aggregation; $\mathrm{RBCD}-$ red blood cell deformability. $\mathrm{PGF}_{2 \alpha}-$ Prostaglandin $\mathrm{F}_{2 \alpha}$.

Table 4

The red blood cell microrheology changes after cell incubation with $\mathrm{Ca} 2+$ cell entry blocker Verapamil and calcium ionophore A23187 $(\mathrm{M} \pm \mathrm{m}, n=24)$

\begin{tabular}{lccc}
\hline Parameters & Control & Verapamil $(10 \mu \mathrm{M})$ & A23187 $(3 \mu \mathrm{M})$ \\
\hline RBCA & $7.18 \pm 0.28$ & $5.88 \pm 0.25^{*}$ & $12.78 \pm 0.54^{*}$ \\
RBCD & $0.212 \pm 0.004$ & $0.250 \pm 0.005^{*}$ & $0.193 \pm 0.004^{*}$
\end{tabular}

${ }^{*} p<0.05$ versus control. For abbreviations, see Table 1.

\section{Conclusion: some probable molecular targets in RBCs for drug microrheological effect}

\subsection{Role of $\mathrm{Ca}^{2+}$ in red blood cell microrheology alteration}

The measurement of the total red cell calcium concentration has yielded values between 5 and $50 \mathrm{nM}$ [22], while only a few percent of total red cell $\mathrm{Ca}^{2+}$ is in an ionized form [27]. Any rise in intracellular $\mathrm{Ca}^{2+}$ in erythrocytes activates a specific $K^{+}$channel ('Gardos' channel) which normally makes little contribution to $K^{+}$fluxes [10]. RBC treatment with stimulators of $\mathrm{Ca}^{2+}$ influx as well as the inhibition of $\mathrm{Ca}^{2+}$ efflux resulted in a significant increase of their aggregation [17]. Contrasting with it, $\mathrm{Ca}^{2+}$ entry blocking into the red cells by verapamil led to a significant RBCA decrease and RBCD rise (Table 4). Our experimental data indicated that the stimulation of $\mathrm{Ca}^{2+}$ influx by $\mathrm{A} 23187$ caused a significant increase of red blood cell aggregation and some RBCD decrease (Table 4).

The changes in $\mathrm{RBC} \mathrm{Ca}^{2+}$ and cAMP content are not simply two isolated linear signaling pathways, but they actually interact at multiple levels to form an effective signaling network.

\subsection{Effect of phosphodiesterase (PDE) activity inhibition on red blood cell microrheology}

It is known that the intracellular cAMP level is regulated by phosphodiesterases (PDEs) [1,5]. To study their role in red cell aggregation alterations the cells were incubated with: $\mathrm{PDE}_{1}$ inhibitor vinpocetine; $\mathrm{PDE}_{3}$ inhibitor cilostazol; $\mathrm{PDE}_{4}$ inhibitor rolipram. The red cell aggregation was reduced after the cell incubation with the above-mentioned drugs, having the PDE inhibitory activity. The most significant effect was found under cell incubation with $\mathrm{PDE}_{1}$ inhibitor - vinpocetine. Taken as a whole RBCA reduction was on the averaged $25 \%$ under these conditions (Fig. 1). On the whole, the obtained data make us believe that PDEs are a part of the cell regulatory system "the cell membrane receptor - G-protein - AC-cAMP complex" and they involved in the RBC microrheological control mechanisms. 


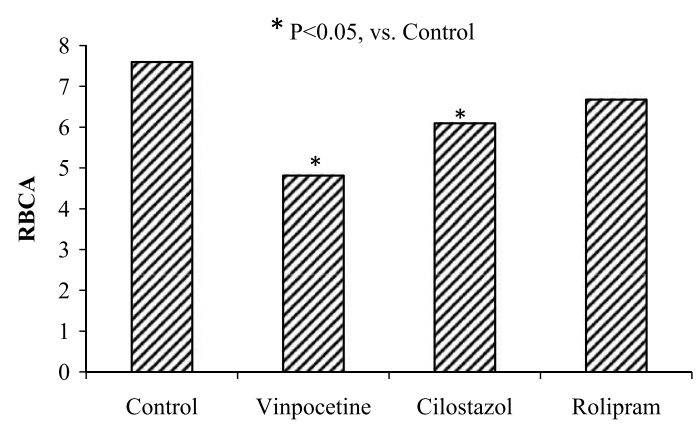

Fig. 1. The change of red cell aggregation (RBCA) after cell incubation with phosphodiesterase inhibitors.

Although the concept that the cAMP and $\mathrm{Ca}^{2+}$ signaling pathways interact at multiple levels was appreciated for some time, an emerging body of data has begun to define specific molecular loci where the two pathways interface. Spotlighting these important molecular loci at which cAMP and $\mathrm{Ca}^{2+}$ signaling pathways converge in non-excitable cells can help us further understand and appreciate the complexity and specificity of stimulus-response coupling in these cells. In the capacity of the potential sites of the cross-talk between $\mathrm{Ca}^{2+}$ and cAMP signaling systems in red blood cells may be PDEs [14]. For example, the constitutive type 4 phosphodiesterase activity rapidly hydrolyzes cAMP so the $\mathrm{Ca}^{2+}$ inhibition of $\mathrm{AC}$ is difficult to resolve, indicating that high phosphodiesterase activity works coordinately with $\mathrm{AC}$ to regulate membrane-delimited cAMP concentrations, which is important for control of cell-cell apposition [5]. Moreover there are data that clearly indicate that the activation of AC and cAMP increase lead to the $\mathrm{Ca}^{2+}$ influx decrease and red cell aggregation and leukocyte adhesion lowering [17, 28]. The similar results were found under the blocking $\mathrm{Ca}^{2+}$ entry into cell or PDE activity inhibition [16].

Taken together the obtained data showed that the drugs infused in blood flow can interact with blood cells, including the most numerous cell population - red blood cells. This interaction can lead to an alteration of RBC microrheological properties and blood transport possibilities at least according to three abovementioned scenarios.

\section{Acknowledgments}

The reported study was partially supported by RFBR, research project No. 14-04-01703 a.

\section{References}

[1] Adderley SP, Thuet KM, Sridharan M, Bowles EA, Stephenson AH, Ellsworth ML, et al. Identification of cytosolic phosphodiesterases in the erythrocyte: A possible role for PDE5. Med Sci Monit 2011;17:CR241-47.

[2] Artmann GM. Microscopic photometric quantification of stiffness and relaxation time of red blood cells in a flow chamber, Biorheology 1995;32(5):553-70.

[3] Bhattacharya S, Chakaborty PS, Basu RS, Kahn NN, Sinha AK. Purification and properties of insulin-activated nitric oxide synthase from human erythrocyte membranes. Arch Physiol Biochem 2001;109:441.

[4] Bishop JJ, Popel SA, Intaglietta M, Johnson PC. Effect of aggregation and shear rate on the dispersion of red blood cells flowing in venules. Am J Physiol Heart Circ Physiol 2002;283:H1985-H1996.

[5] Creighton JR, Masada Nanako, Cooper D, Stevens T. Coordinate regulation of membrane cAMP by $\mathrm{Ca}^{2+}$-inhibited adenylyl cyclase and phosphodiesterase activities. Am J Physiol Lung Cell Mol Physiol 2003;284:L100-07. 
[6] Dawson DL, Zheng Q, Worthy SA, Charles B, Bradley DV Jr. Failure of pentoxifylline or cilostazol to improve blood and plasma viscosity, fibrinogen, and erythrocyte deformability in claudication. Angiology 2002;53:509-20.

[7] Endres S, Semmler J, Eisenbut T, Sinba B. The role of cyclic adenosine 3,5-monophosphate in suppression of tumor necrosis factor- $\alpha$ synthesis: Effect of pentoxifylline. Leukocytes and Endothelial Interactions. Prous Science. Barcelona, 1995, pp. 59-69.

[8] Ernst E. Pentoxifylline for intermittent claudication: A critical review. Angiology 1994;45:339-45.

[9] Hines PS, Zen Q, Burney SN, Shea DA, Ataga KI, Orringer EP. Novel epinephrine and cyclic cAMP - mediated action on BCAM/Lu - dependent sickle (SS) RBC adhesion. Blood 2003;101:3281-87.

[10] Hoffman JF, Joiner W, Nehrke K. The hSK4 (KCNN4) isoform is the $\mathrm{Ca}^{2+}$-activated $\mathrm{K}+$ channel (Gardos channel) in human red blood cells. Proc Nat Acad Sci USA 2003;100:7366-71.

[11] Jung F, Erdlenbruch W, Koscielny J, Kiesewetter H. Influence of hyper-/isovolaemic haemodilution with hydroxyethyl starch on blood fluidity, blood flow and tissue oxygen tension in patients with POAD stage II. Clin Hemorheol 1995; 15: 415-21.

[12] Kovacs IB, O'Grady J. Prostacyclin increases filterability of normal and rigidified human red blood cells in vitro. Agents Actions 1984;14:306-10.

[13] Manno S, Takakuwa Y, Mohandas N. Modulation of Erythrocyte Membrane Mechanical Function by Protein 4.1 Phosphorylation. J Biol Chem 2005;280:7581-87.

[14] Manns JM, Brenna KJ, Colman RW, Sheth SB. Differential regulation of human platelet responses by cGMP inhibited and stimulated cAMP phosphodiesterases. Thromb Haemost 2002;87:873-79.

[15] Minetti G, Ciana A, Balduini C. Differential sorting of tyrosine kinases and phosphotyrosine phosphatases acting on band 3 during vesiculation of human erythrocytes. Biochem J 2004;377:489-97.

[16] Muravyov AV, Yakusevich VV, Maimistova AA, Chuchkanov FA, Bulaeva SV. Hemorheological efficiency of drugs, targeting on intracellular phosphodiesterase activity: In vitro study. Clin Hemorheol Microcirc 2007;36:327-34.

[17] Muravyov AV, Tikhomirova IA. Role $\mathrm{Ca}^{2+}$ in Mechanisms of the Red Blood Cell Microrheological Changes, In: Calcium Signaling, Md. Shahidul Islam ed, Springer Science+Buisness Media, Dordrecht; 2012. P.1017. DOI: 10.1007/978-94007-2888-2 47.

[18] Oonishi K, Sakashita N, Uysaka N. Regulation of red blood cell filterability by $\mathrm{Ca}^{2+}$ influx and cAMP-mediated signaling pathways. Am J Physiol Cell Physiol 1997;273:C1828-34.

[19] Pindur G, Sander A, Seyfert UT, Fung J. The effect of pentoxifylline on the deformability of erythrocytes in erythrocyte concentrates in additive solution Anasthesiol Intensivmed Notfallmed Schmerzther 2001;36:Suppl 1, S59-61.

[20] Pitter JG, Szanda G, Duchen MR. Prostaglandin $F_{2} \alpha$ potentiates the calcium dependent activation of mitochondrial metabolism in luteal cells. Cell Calcium 2005;37:35-44.

[21] Pries AR, Secomb TW. Rheology of the microcirculation. Clinical Hemorheology and Microcirculation 2003;29:N3-4, 143-148.

[22] Romero PJ, Romero EA. The role of calcium metabolism in human red blood cell ageing: A proposal. Blood Cells Mol Dis 1999;25:9-19.

[23] Sager G, Jacobsen S. Effect of plasma on human erythrocyte beta-adrenergic receptors. Biochem Pharmacol 1985;34: 3767-71.

[24] Starzyk D, Korbut R, Gryglewski RJ. Effects of nitric oxide and prostacyclin on deformability and aggregability of red blood cells of rats ex vivo and in vitro. J Physiol Pharmacol 1999;50:629-37.

[25] Sundquist J, Blas S, Hogan JE, Davis FB, Davis PJ. The alpha 1-adrenergic receptor in human erythrocyte membranes mediated interaction in vitro of epinephrine and thyroid hormone at the membrane $\mathrm{Ca}(2+)$-ATPase. Cell Signal 1992;47: 95-99.

[26] Tang LC, Schoomaker E, Wiesmann WP. Cholinergic agonists stimulate calcium uptake and cGMP formation in human erythrocytes. Biochim Biophys Acta 1984;772:235-38.

[27] Wiley JS, McCulloch KE. Calcium ions, drug action and the red cell membrane. Pharmacol Ther 1982;18:271-92.

[28] Yang Y, Luo J, Kazumura K, Takeuchi K, Inui N, Hayashi H, Ohashi K. Cilostazol suppresses adhesion of human neutrophils to HUVECs stimulated by FMLP and its mechanisms. Life Sci 2006;10:629-36. 